\title{
THE FOUNDING OF THE UNIVERSITY OF MELBOURNE, 1852-1855
}

\author{
R.J.W. Selleck
}

At the end of Hubert Evans's subtle novel, O Time in Your Flight, the young hero's family, in search of better times, is preparing for the journey from southern Ontario to British Columbia. "The trouble was," the boy reflects,

you never knew if the next place would be your promised land until you got there. Until you did, your promised land was all inside your head. Would British Columbia tum out to be his promised land? And would a whip-poor-will be singing there? ${ }^{1}$

Even when you get there, and even if a whip-poor-will is singing, promised lands can still be all inside your head. And often you never get there, never find the promised land, but joumey on carrying the idea in your head as a guide in your wanderings.

In part this paper is about ideas, especially those held by some men in nineteenth-century Melbourne who set about establishing a university. They had carried a set of ideas about what a university should be with them as they journeyed across the world, some of them in search of a promised land. They found that tuming these ideas into reality was complex and disappointing, but their struggle sheds light on the social, political, and educational life of Antipodean society.

In the early 1850 s, as moves were being made to found a university in Melbourne, ideas about universities were particularly controversial. In fact John Henry Newman was adding to the controversy by writing The Idea of a University. The American historian Sheldon Rothblatt, in his The Idea of a University and its Antithesis, ${ }^{2}$ has argued that American universities had and have no idea of a university - they represent its antithesis. Newman would have argued that Melburnians had no idea either, that is, if he had known that anyone had the idea of establishing a university in Melboume. But as Newman worked in Dublin clarifying his idea of a university, the Irish lawyer Redmond Barry, who had spent

1. Hubert Evans, O Time in Your Flight (Vancouver: Harbour Publishing, 1979), 235.

2. Melbourne, 1989. 
his university days in Dublin at Trinity College, struggled to establish the University of Melbourne, of which he had been appointed the first Chancellor. Over one hundred years later, to honour his contribution, the university named a large and shoddy building after him. It does not epitomize Barry's idea of a university.

It is a matter of some difficulty to decide when the University of Melbourne was founded: 1852, when the Act to establish it was introduced into Parliament; 1853, when its first Council was appointed; 1854, when the foundation stone was laid; or 1855 , when the first students were enrolled. This paper, which is concerned to understand what the founders of the University of Melbourne wanted it to be and to do, begins by concentrating on the laying of its foundation stone because that event provides an opportunity to see the power-brokers of Melbourne society expressing themselves explicitly through ritual and, at the same time, enables us to catch them off-guard in a moment of celebration. They can be watched making their university, deliberately building an institution, constructing it after a particular image. Then the paper tests their idea of a university by looking, necessarily briefly, at the answers they gave to three crucial questions: who should teach in a university? how should they teach? and what should they teach?

ON 3 JULY 1854, a fine winter's day, Sir Charles Hotham, the Lieutenant-Governor of Victoria, waited outside the Government Offices in William Street, Melbourne, while carriages holding ladies and gentlemen of the city were arranged in order of rank. Precedence mattered; so care was taken to position the representatives of the Masonic lodges appropriately-after the Grand United Order of Oddfellows but before the general body of the inhabitants. Shortly after noon the governor's carriage, flanked by mounted police and followed by a long line of pedestrians, led the procession to a paddock about one-and-a-half kilometres north of the city. Wheeled vehicles like those of Hotham's entourage had churned the surface of the ground into mud. Extensive excavations, caused by the removal of loam, earth, and clay, were filled with water; huge tree-stumps were all that remained of the native timber, and rubbish covered acres of the paddock. On this ugly site, set on rising ground between Melbourne's cattle yards and its New Cemetery and despoiled by the search of Europeans for wealth, shelter, and comfort, Hotham had come to lay the foundation stone for one of Europe's cultural triumphs, a university. ${ }^{3}$

3. Argus and Melbourne Morning Herald, 4 July 1854; Belfast Gazette, 15 July 1854. The description also draws on Geoffrey Blainey, A Centenary History of the University of Melbourne (Melbourne: Melbourne University Press, 1957), 8, and Ernest Scott, A History of the University of Melbourne (Melbourne: Melbourne University Press, 1936), 15. Redmond Barry to Worshipful Master of Masonic 
A fence to restrain the crowd, thus making possible a physical and a symbolic distance, had been erected around the space which the building would eventually occupy. Inside the fence, raised seats had been built around three sides of the spot where the stone was to be laid. Though the university had as yet no physical existence, its ceremonial robes had been chosen and Redmond Barry, wearing 'the very handsome robes' of the Chancellor's office, conducted Lady Hotham to her seat under a canopy. She and her husband inspected the plans of the building and expressed themselves satisfied, perhaps because, as the Argus had earlier remarked, the building was designed after English models 'which time has long since consecrated.' The Argus was less satisfied with the attendance: the spectators were fewer than expected for such an important occasion, and ladies were not numerous, though there were enough of them, a rival newspaper noted, to 'shed an air of elegance and refinement over the whole affair."

Mr. Justice Barry, who had contributed to the elegance of the occasion by pestering the city's Council to prevent the dumping of manure in front of the university's grounds, gave a lengthy speech which the Argus had difficulty in reporting, because ' $w$ hen the learned gentleman desired to be most impressive he became the least audible.' But the paper recorded his view of the significance of the occasion; his laboured gallantry towards Lady Hotham; his pleasure in the progress of the colony (scarcely seventeen years ago, he said, the spot on which they stood 'was inhabited only by savages'); and his expectation that the newly discovered mineral resources would make progress still more rapid. Walking along Sydney Road on the western edge of the paddock, diggers heading for the goldfields to mine for those resources (and carrying their paradise all inside their heads) could see the assembly of their betters, though if the Argus is to be believed, Barry's protracted and ponderous eloquence would not have troubled their ears.

The foundation stone was actually two stones: one had been placed in the ground and above it another was suspended from cross-trees on which flew flags of various colours and designs. After Hotham had given a speech in reply to Barry's, some coins and the constitution of the university were placed in a cavity in the lower stone for future generations to discover. The cavity was covered with a brass plate which carried a Latin inscription composed by Barry, some details about the laying of the stone, and the Latinized names of the first Council and of the architect and the builder. The inscription indicated that the university had been 'instituted in honour of God, for establishing young men in philosophy, literature and piety, cultivating the talent of youth, fostering the arts, [and] extending the bounds of science.' Hotham spread some mortar with a silver

Lodges, 29 Apr. 1854, University of Melbourne Council Letter Book [CLB], 1854-71, University of Melbourne Archives [UMA].

4. Argus, 30 June and 4 July 1854; Melbourne Morning Herald, 4 July 1854.

5. Barry to Mayor of Melbourne, 19 June 1854, CLB, 1854-71; Argus, 4 July 1854. 
trowel, the upper stone was lowered, and, tapping it with a mallet 'in Masonic fashion three several times,' the Argus noted, Hotham declared it well laid. According to the Argus the stone was to last, 'like the edifices of the old country,' for centuries. ${ }^{6}$ It may still be lasting well but, as no one now knows where the stone is, it is impossible to be sure. Perhaps the stone masons incorporated it into the building where it stands, anonymous and unrecognized, with the names of its important men and Barry's Latin prose hidden even from the interested.

After three cheers had been given for the governor, his lady, the Queen, and the university, the procession moved down Swanston Street towards the city. It stopped (by then it was three o'clock in the afternoon) at the corner of La Trobe Street where a large crowd had gathered. In a ceremony similar to that which had just been completed, the Speaker of the Legislative Council, Dr. James Frederick Palmer, gave a long speech and Hotham laid the foundation stone for the Melbourne Public Library. He puzzled in his speech over which was the more important of the foundation stones he had laid that day. ${ }^{7}$ For Redmond Barry, who was Chairman of the library's Board of Trustees, and for the city itself, it was a day of cultural triumph.

The press made no secret of its views. Melbourne, the Argus decided, with the university particularly in mind, was to be 'the metropolis of the Southern Hemisphere' not only through commerce or the development of its resources but by scientific achievements. It was fast becoming 'the glory of the South, and the civiliser of the East.' Remarking on the recent separation of Victoria from New South Wales, the Melbourne Morning Herald commented that there was no instance of a university being founded by a state within two years of 'its political birth and the acquisition of legislative power.' After all, Oxford and Cambridge had taken centuries to do what Melbourne had done in a few years. More importantly, perhaps, the Herald asserted that 'our claim to superiority in this respect over the neighbouring colony of New South Wales admits of no dispute, and it is to be hoped will be cheerfully and ungrudgingly accorded. ${ }^{8}$

In 1854 Melboume was not yet 'marvellous' (that took until the 1880s), but it was an extraordinary city, the capital of a colony which four years earlier had not existed. Until the passage of the Australian Colonies Government Act in 1850 'Victoria' had been the Port Phillip District of New South Wales and was governed from Sydney, an arrangement which had grown increasingly irksome. From the early 1830s sealers and whalers, such as the Hentys who left Van Diemen's Land and settled at Portland, established permanent European settlements in the District. In 1835 John Batman came from Van Diemen's Land to the place that became Melbourne, planning to use it as a base from which he

6. The inscription is preserved in full in the reports of the Argus and Melbourne Morning Herald of 4 July 1854; Banner and Argus, 4 July 1854.

7. Argus, 4 July 1854.

8. Argus and Melbourne Morning Herald, 4 July 1854. 
would send sheep to colonize the pastures he had obtained from the Aborigines in a demeaning treaty. However, the sheep brought across Bass Strait were rapidly outnumbered as overlanders from New South Wales, often with their eyes turned greedily towards Victoria's western plains, brought thousands of sheep and, for a token fee or for nothing, squatted on blocks which varied from 10,000 to 50,000 acres. By 1851 the six million sheep in the colony equalled the number of sheep in what would now be called New South Wales, and the European population of Victoria was 77,000 , more than double what it had been five years earlier. ${ }^{9}$

This population grow th was rendered trivial by the discovery of gold in 1851 . In the early days of alluvial mining, news spread of fortunes easily won, and great rushes took place to Ballarat, Mount Alexander, and Bendigo. By the end of 1851 about half the men in Victoria were at the diggings. Thousands had rushed from the neighbouring colonies-Tasmania and South Australia swiftly lost half their men. Immigrants poured in from Europe, especially from England, Scotland, and Ireland, in a terrifying flood. In the decade to the end of $1861,584,000$ persons migrated to Victoria and its population multiplied more than five times over. It had been remade so dramatically that in December 1854,86 percent of the Europeans in the colony had come in the previous three years. ${ }^{10}$ European Victoria was a society of migrants, scrabbling for gold in the corner of a huge country at what they considered was the edge of the world.

While the newly independent Victoria exulted as it became, for a short time, a subject of international attention, its embryonic institutions collapsed before the lure of gold. In the early months of the rushes, thirty-eight of Melbourne's forty metropolitan police resigned, tradesmen, shop-keepers and civil servants fled the city, ships lay idle in Hobson's Bay deserted by their crews, schools and shops were closed, crime increased, women and children were abandoned in Melbourne while men dug frenetically for gold and, if they found it, returned to the city for riotous carousing. Accommodation was entirely inadequate, and until late in 1853 people (at one time seven thousand of them) camped in tents in the swampy ground of Canvas Town, west of St. Kilda Road within sight of Princes Bridge. Government had almost collapsed. By the time the foundation stone of its university was laid, order had retumed, but Melbourne remained a raw, suddenly rich city, confronting political, social, demographic, and economic pressures which would have dislocated a city with soundly established institutions and

9. Graeme Davison, The Rise and Fall of Marvellous Melbourne (Melbourne: Melbourne University Press, 1978); Geoffrey Blainey, Our Side of the Country (Sydney: Methuen and Haynes, 1991), 16-19, 36.

10. Blainey, Our Side of the Country, 39; Richard Broome, The Victorians: Arriving (Sydney: Fairfax, Syme, Weldon, 1984), 67; Geoffrey Serle, The Golden Age: A History of the Colony of Victoria, 1851-61 (Melbourne: Melbourne University Press, 1963), 382; Broome, The Victorians, 76. 
stable government. Its streets served as a symbol of its condition. Even the most important were so muddy and hazardous that only the well shod could comfortably negotiate them, and the press gave daily instruction as to which streets leading to 'places of popular resort' were passable and which unsafe. ${ }^{11}$

The ceremony at the laying of the foundation stone expressed the power, the social and cultural beliefs, and the fears of those who ruled this strange city: the Lieutenant-Governor representing the colonial power, the procession constructed in order of rank, the carriages of the powerful, the site chosen on rising ground, the designing of the building along 'the simple gothic style of Henry VI,' speeches by powerful men, the fence built around the site to control the ordinary inhabitants, the mounted police, Lady Hotham's canopied seat, the carefully chosen robes of ecclesiastical origin (Hugh Childers, the university's first ViceChancellor, consulted a previous Registrar of Cambridge before deciding what was fitting for a Vice-Chancellor to wear), the titles-Vice-Chancellor and Chancellor, the limiting of women to the bringing of elegance, the reduction of indigenous people to savages and of the 'East' to a place that needed civilizing, the coins and constitution over-confidently trusted to the future, the self-righteous superiority to Sydney, the Latin language and Masonic rituals, the honouring of God and learning. Above all, perhaps, the titles. By calling the new institution a 'university,' by so using the power of naming, its founders had given it, in an instant, a history stretching back through the centuries to medieval Europe. As well, by naming it after Lord Melbourne, who had been Prime Minister of England when the city received its European foundation, the founders made the university (as they had made the city) part of the brief history of British imperialism, which did not recognize the history of the indigenous people, measured not in centuries but millennia. Captured in word and ceremony and ritual, the daring visions and the frightening blindness of a small colonial (and colonizing) civilization were exposed on a winter afternoon in a paddock near Sydney Road.

Those who described the scene shivered at some of its implications. The 'heavy shadows and the echoes of the cloisters' were palpable to their senses. The Argus reported that the Governor was surrounded by 'the tinselled and begowned officials in "church and state," and the associations produced by the scene were aristocratic and academical. ${ }^{, 12}$ For many present those aristocratic and academical associations were exemplified by the universities of Oxford and Cambridge, which were being reformed even as the fledgling university in

11. Blainey, Our Side of the Country, 39-40; Broome, The Victorians, 74-77; Serle, The Golden Age, 29-36, 68-69; Spencer Childers, The Life and Correspondence of the Right Hon. Hugh C.E. Childers 1827-1896 (London: Murray, 1901), 42; Emily Childers diary, 25 Aug. 1852 (in possession of Dr. Martin Sullivan, Monash University); Melbourne Morning Herald, 11 July 1854.

12. Argus, 30 June and 4 July 1854 . 
Melbourne was coming into existence. But it was old, unreformed Oxford and Cambridge that most colonists with university experience knew, and it is hard to understand the University of Melbourne without reflecting on these ancient institutions.

All around the boundaries of Oxford and Cambridge yawned the moat of class division, and inside the moat the curriculum offered to students was profoundly influenced by the same class consciousness. These universities gave a predominantly literary and classical education: the study of the ancient Roman and Greek civilizations and their languages, some mathematics, but not the modern studies, especially not science. At its worst, which it often was, this was dull grammarian drudgery; at its best it was a diverse and rich intellectual feast, humane and challenging. In the practical, vocational sense, it was a useless curriculum. Medicine might serve as an example. Edinburgh's famous medical school was proudly professional, introducing its students as an integral part of their course to hospital wards and dispensaries as well as teaching them anatomy, surgery, chemistry, and such subjects. At Oxford a would-be doctor learned how to participate in the culture of his wealthy patients, but his professional medical studies were done elsewhere.

Oxford and Cambridge offered an education designed for aristocrats and, increasingly, for the students from middle-class families with newly acquired wealth and political power who, in an act of extremely successful self-protection, were being introduced into the circles which ruled England. When you can't beat them, you don't join them, the aristocracy had decided; you get them to join you. As financial and political power began to pass into the hands of the middle class, Britain's hereditary rulers set about seducing it. They offered a glittering but relatively inexpensive prize, a share of the culture which sustained them, the chance to become like them. Oxford and Cambridge devoted themselves to this process of seduction and worked their charm for more than a century. If you are not careful they can still work it. Beware of dreaming towers and church spires. Beware of them, even in colonial buildings!

Oxford and Cambridge were educating the leaders of church and state. When a student entered an Oxford college, he (women were not admitted) was offered more than knowledge, he was initiated into a culture, a way of living. What matters most was not the discovery of new knowledge, which the modern university values, but the inculcation of received values through a process of immersion. As Sheldon Rothblatt has said, speaking directly of the universities of this period and of John Henry Newman:

The intellectual life is only one kind of life led in universities...there is another aspect to leaming which is also essential, a more human aspect, in which personal relationships matter, friendships count, and success is measured not by examinations, however necessary these may be for determining a certain level of competence, but by growth and maturation, by what, in a memorable passage on the qualities of a gentleman, Newman described as civilised behaviour. 
In this conception of a university the greater value is accorded to 'the entrance [to university] rather than the exit, selection rather than certification, matriculation rather than graduation,' to having been through university rather than having been a highly successful examination candidate. ${ }^{13}$ Being as much interested in character as in intellect, this conception of a university is not afflicted with the illusion that students can be made entirely rational and independent thinkers. It works on the understanding that all leaming is a social activity deeply influenced by the values and beliefs and power of those who offer it, by the way they behave as well as by what they advocate, by the way they speak as well as what they say. It is a conception which values the imitation of models, the formation of habits, the initiation into a culture, and not primarily the introduction to a body of knowledge, though it values some forms of knowledge more highly than others.

The collegiate nature of Oxford and Cambridge, one of their most striking characteristics, embodies this conception. The university was a distant institution which awarded degrees, but it was the college to which the student was admitted, in which he was taught, and in which he lived. The college was a self-satisfied, self-contained society, so self-contained that it bent nature to its purposes and 'the very names of the rivers were changed as they approached the universities,' the Thames in Oxford becoming the Isis. ${ }^{14}$ As the Church and the Army knew from long experience, having young men live in institutions which are separated from the ordinary community can be a powerful educative experience. The college's explicit values, but more importantly, its customs, its carefully preserved traditions, its rituals, its initiation ceremonies, its celebrations and songs, the slang it used, the parties its students held-its culture in short-was immensely influential. Its impact can be conveniently captured in the verse featuring Benjamin Jowett, a tutor and later Master of Balliol College. 'This is Balliol, I am Jowett,' the verse went,

All there is to know I know it;

What I don't know isn't knowledge;

I am Master of this College.

Because the college was residential, alternatives to its culture were temporarily removed, and could be mocked with impunity and their inferiority made evident. Not only were these colleges residential, they were in the country, as were most of the Public Schools from which their students had come. Oxford and Cam-

13. Sheldon Rothblatt, The Idea of a University and its Antithesis (Melbourne: La Trobe University, 1989), 9, and 'Historical and Comparative Remarks on the Federal Principle in Higher Education,' History of Education 16, 3 (1987): 153.

14. Quoted from an unpublished paper by Tony Taylor, 'Oxford and Cambridge in the 1850 s-Religion, Reform, and the Idea of a Liberal Education.' 
bridge experienced the struggle of town and gown, but knew little directly of the forces which had made places such as Manchester, Liverpool, Birmingham, and Leeds the sites of social dislocation and unrest. Monastic reasons, particularly the separation of pupils from the moral distractions of the city and the search for the silence and isolation conducive to things of the mind and spirit, had played a part in the locating of the universities in Oxford and Cambridge. In any case it was natural enough that the aristocracy, who still derived much of their wealth and power from land, should be attracted to institutions in rural locations. And if the children from the ambitious urban middle classes, whose wealth was derived predominantly from manufacturing, followed them there, that was all the better. They could be the more thoroughly introduced into the aristocratic culture.

In this introduction the classics played a crucial role. They symbolized discipline and methodical self-control, they gave access to a culture unconnected with the business of making a living, they marked social boundaries and made possible allusions which only the initiated could share, they were the embodiment (and the remnant) of past rich and powerful cultures, and they gave access to the culture of the rich and powerful in the present. ${ }^{15}$

It was not only through the classics that the colleges expressed and reinforced the class structure. Aristocratic students, the 'noble commoners,' shared privileges with the College fellows, had special caps and gowns to distinguish them from the other students, and could graduate without taking an examination. In fact reading for a degree, especially an honours degree, was often thought beneath their dignity. The very few working-class students who obtained entry, and who were called servitors at Oxford and sizars at Cambridge, might serve the noble commoners as they dined at high table with the fellows.

To this support for the class system must be added support for religion. Even at the risk of labouring the obvious, it is necessary to remark that Oxford and Cambridge were religious institutions, extensions of the Established Church. To obtain a degree their students were, or had to say they were, members of the Church. To be a fellow, an appointment made for life and usually accompanied by a comfortable stipend, it was necessary to be in Holy Orders and unmarried. Oxford and Cambridge opened the privileged gates to power, and their ability to decide who should have the opportunity to pass through those gates ensured that the country remained a club which was in good hands, those of decent Churchmen and honourable chaps.

Chaps. That was the other exclusion. Women's struggle for political, financial, and personal autonomy had begun but there was no place for them, either as student or teacher, in the mid-nineteenth-century universities. These powerful institutions were, in terms of class, religion, and gender, severely

15. Christopher A. Stray, 'From Monopoly to Marginality: Classics in English Education since 1800,' in Social Histories of the Secondary Curriculum, ed. Ivor Goodson (Lewes: Falmer Press, 1985), 19-51. 
exclusive and precisely adjusted to a specific social task. Having a sense of mission, they did not need mission statements. They worked in a less explicit but ultimately more powerful way: they expressed their values in a way of living and had their future leaders live it when they were young.

OF THE TWENTY NAMES of the University of Melbourne's first Council engraved on that lost foundation stone, twelve had been to university, and for nine of the twelve that experience was collegiate-they were products of Oxford, Cambridge, or Trinity College, Dublin. In the design they approved for the new university they sought to recreate that experience, Oxford's particularly, through the Tudor Gothic quadrangle and cloisters of the university's first building. By the early 1870 s on a winter morning a student or a professor could look at this building, shrouded in fog across the university's lake, and for a moment imagine that something of Oxford had been transplanted into colonial Melbourne.

Something had been transplanted, but much less than the building suggested, because the social, political, and economic system which nurtured Oxford could not be brought to Melboume. Even before gold, Melbourne was not a classless city, but the class structure was uniquely colonial. There was no hereditary aristocracy accustomed to wielding power in and out of Parliament, no squires, no lords or ladies of the manor. There was no powerful middle class with its roots in industrial manufacturing. There was no established church, though the Australian Church of England, with calculated absence of mind, sometimes acted as if it had been established. Faced with establishing a university, therefore, the professional men, pastoralists, and businessmen who made up the first Council produced an institution whose structure was very different from the universities which they had attended and which they evoked in the architecture of the building by the lake.

In the absence of wealthy churches or families with great fortunes seeking to be remembered or made respectable by endowing a university, the founders turned, as Australians did when they wanted to establish schools, or build roads or bridges, hospitals or police stations, to government. The University of Melbourne, like all Australian universities until the last decade, was a state university. It charged fees but it was established by Act of Parliament and directly funded by government.

The University of Melbourne was also secular, explicitly, intentionally, and from the beginning. There was no religious test for students, no theology was to be taught, no clergyman could be appointed to its staff, no professor could teach religion on or off its campus. The struggles over elementary education in the Australian colonies had shown the churches to be powerful and jealous, and Redmond Barry and his colleagues did not want to repeat those controversies at the university. They eliminated them by making the university secular, though how they managed to get unanimity for secular education of the leaders of the community when they could not gain it for popular education remains a mystery. 
The University of Melbourne was also a city university, as were all nineteenth-century Australian universities. The city of Melbourne and the colonial administration welcomed the university so that the town and gown disputes of Oxford and Cambridge never threatened Melbourne. The city's council granted the university land, adapted its original grant to enable the university's buildings to occupy the central site the architect wanted, and even extended the grant slightly so that it would include two good trees and some land in the northeast corner where there was a natural site for a future lake. The city was even willing to change the local street-scape to produce a space which was to be planted as a square and to give those approaching from the city an unimpeded view of the front of the University - one of Melbourne's 'chief architectural monuments,' the university's registrar called it. This vision was not shared in some country districts. The Portland Guardian, for example, complained about the new institution being the university of Melbourne, arguing that money was being squandered on 'one ornamental building in the Tudor style' when a more sensible plan would have been to establish collegiate buildings in other parts of the colony. ${ }^{16}$ But a city university Melboume emphatically was. Indeed having a university was an assertion of civic responsibility and importance, especially if Sydney had one.

Not only was the university an urban, state-controlled, and secular institution, it was also to be egalitarian or at least meritocratic. The University of Melbourne, said Redmond Barry, who was not instinctively democratic, was to be 'open to all classes of her majesty's subjects who are freely invited to enter...and continue as on an equal footing for the honours and substantial dignities to be awarded on merit alone. ${ }^{17}$ No noble commoners or servitors here! The proclamation of this principle was not accompanied by measures which made its attainment possible, but even the intention marked a significant change from precedent.

Once a secular, state, and egalitarian university was established there was no place for colleges on the model of Oxford, Cambridge, or Dublin. The cultural function they performed was not needed, and the religious and class dominance they buttressed did not exist in Melbourne. Or Sydney, for that matter, though Sydney tried much harder to establish a collegiate model. The traditions, rituals, and ceremonies of college life could be copied in Australia, and they were, and still are, but from the beginning they have been empty of their original meaning, and remain more or less powerful means of self-deception-efforts to make

16. Mackinnon to Colonial Secretary, 16 Feb. 1854; Surveyor-General to Colonial Secretary, 3 Apr. 1854; John James (Registrar) to Charles Gavan Duffy, 8 Sept. 1856 - all in land file, UMA; Portland Guardian, 13 July 1854.

17. Quoted in P.W. Musgrave, From Humanity to Utility: Melbourne University and Public Examinations 1856-1964 (Melbourne: Australian Council for Educational Research, 1992), 16. 
believe that England could be built again in the dry unpleasant land of Australia. It could not. 'An importation of the University or Collegiate system of the Mother Country into this, with an unbending and rigid extortion of conformity to its provisions, is simply impossible,' said Redmond Barry. ${ }^{18}$

But, oh how hard some people tried! The crescent around the northern boundary of the university contains a number of nineteenth-century buildings set in beautiful gardens. The land it encloses was intended from the beginning to contain colleges built by the churches, though it was not given to the university, despite intense pressure from Barry. The churches have built the colleges and the colleges have appointed masters, though unlike Jowett they could never boast that they decided what counted as knowledge. The university, that is, ultimately, its Council, decided what would be taught, appointed the staff to teach it, admitted and examined the students. To the decision as to what knowledge was of most worth, and to the dissemination of that knowledge, the colleges contributed very little. Of course, they provide residential life, tutors, and libraries for the students of wealthy parents, and in that way contribute to the preservation of socio-economic privilege, but they are essentially halls of residence and not colleges in the older sense of that word. Tin Alley, the narrow road that separates the colleges from the university, marks the divide set up in the nineteenth century between church and state in Australian higher education. On the one side the churches, on the other side the state; on the one side the colleges, on the other the university; and it was the state as represented by the university, and not the church as represented by the colleges, which held the power.

Almost as if to stress their inferior status, the first college, Trinity, was not opened until 1872, eighteen years after the first students had been enrolled. The colleges remain, physically and metaphorically, on the periphery of the university. From the point of view of Jowett or Newman, who could not conceive of an Oxford without the collegiate experience, the marginality of the colleges reduced the University of Melbourne to a vulgar department store in which a debased form of learning was offered to ill-informed and uppity customers. A sort of Safeways of the mind!

Redmond Barry, of course, had another view and, well before the foundation stone of the university was laid, he made arrangements to recruit its first staff. Following the example of the University of Sydney, the Council appointed a committee of five men in England, under the chairmanship of Sir John Herschel, the eminent astronomer and mathematician, to search for suitable professors.

The decision to appoint professors marked a pedagogic and a social choicea rejection of the collegiate institution, of tutors and fellows who expounded a text to small groups of students in private residential institutions, in favour of a university where professors, who claimed expertise in a particular subject or

18. Proceedings on the Occasion of the Inauguration of the University of Melbourne (Melbourne: Government Printer, 1855), 14. 
subjects and were appointed by the university, not a college, lectured non-residential students in public. Professors professed, claimed knowledge of a particular science or art, and the chair from which they taught came to symbolize their office. ('Chair' derives from 'cathedra,' and is part of the family from which 'cathedral,' the seat of a bishop, comes and, of course, 'ex cathedra.') Professors symbolized a view of education which gave primacy to the communication of knowledge, while of course they believed, as children of the Enlightenment, that knowledge helped to develop personal character and civilized behaviour. Certainly professors introduced students to knowledge valued by the powerful, but they showed by what they taught and, equally, by their manner of teaching it, that they were not endeavouring to induct students into a way of living, an exclusive culture. Professors also epitomized an individualized model of learning: each student took what he could from a professor's lecture, constructing his own body of knowledge. This was a far cry from the college, where learning centred around a classic text and the way of life and learning was social and communal.

In discussing the professors to be appointed Barry gave Herschel and his colleagues a clear picture of what he wanted. Clearly marking out a difference from Oxford and Cambridge, he stressed that the University of Melbourne was one of 'comprehensive liberality'-there were to be no religious tests. The professors were not to be in Holy Orders, they were to be totally abstracted from 'political or sectarian interference,' under middle age, graduates of Oxford, Cambridge, London, Dublin, Edinburgh, or Glasgow, and, said the Irishman Barry, ready to 'stamp on their future pupils the character of the loyal, well-bred Englishman.' 19

London was an interesting inclusion in this list of universities for it was a new and bitterly contested phenomenon. Given a charter by government in 1836 , it was purely a degree-granting institution, and in that capacity it was secular. The colleges affiliated with it (at that stage there were two) received no government funding but might reflect the religious views of their founders. As it happened, London did not provide any professors for the infant University of Melbourne, nor did the Scottish universities. Indeed Barry's list of universities produced only one of the first four professors recommended by Herschel-the Professor of Classics, Henry Erskine Rowe, came from Cambridge and made a minimal impact on Melboume as he died only a month after his arrival. But Herschel had fully understood Barry's preferences for the other three professors came from the Queen's University in Ireland. The Colleges (Ireland) Act of 1845 enabled the opening at Belfast, Galway, and Cork of colleges financed by the state, which were non-residential, had no religious test, and were secular in the sense that no theological or religious education could be provided from the state's grant, though it could be privately endowed. In 1850 the Queen's University in Ireland was set up, somewhat after the model of the University of London, as an

19. Barry to selection committee, 26 Jan. 1854 , CLB, 1854-71. 
institution which would establish degrees, conduct the examinations for which students from the three colleges might sit, and confer the degrees. To Herschel it represented the Melbourne model: it was non-residential, state-funded, secular, and professorial in organization. ${ }^{20}$

What did these newly appointed professors teach? Their fields of expertise covered the classics and ancient history, mathematics, the natural sciences, and (a single chair) modem history, literature, and political economy. The wide range of studies indicated the university was trying to respond to the demands of colonial life and to place less value on the classics. Moreover, Melbourne paid each of its professors the same salary, unlike the University of Sydney, which paid differential salaries to indicate status-the salary of the professor of classics being double that of the professor of experimental philosophy and science. ${ }^{21}$

But writing to Herschel, Barry gave a different message. He admitted that there was a need for the teaching of the natural sciences-geology, metallurgy, mineralogy, chemistry, natural history, and physiology - if only because many questions could not be answered in the colony and had to be referred to England. Herschel's committee took Barry seriously by appointing Frederick McCoy, who had taken part in the geological survey of Ireland, had written two books on the limestone and Silurian fossils of that country, and was Professor of Geology and Mineralogy at Queen's College, Belfast. Yet Barry warned Herschel that a society engrossed in the pursuit of material wealth might overvalue science and regard the classics as 'rather superfluous embellishments.' He did not intend to let that happen and he insisted that the professor of classics had to be 'of hopeful, persevering and constant mind' so that the classical taste of the country would be moulded in the new university. 22

Barry practised what he preached, in this matter at least. He insisted that in the matriculation examination Latin and Greek were to be compulsory, and he did so despite the opposition of the professorial board formed by the newly arrived professors. Barry carried Council, and did so again when the professorial board resisted his determination to make the classics compulsory for the Bachelor of Arts Degree. William Edward Heam, the professor of modern history and literature, political economy, and logic, and William Wilson, the professor of mathematics, published a pamphlet in 1855 arguing that the classics should not be made compulsory. Parents did not want their children to learn the classics and saw them as being without a use, the two professors said; they were a bad

20. T.W. Moody and J.C. Beckett, Queen's, Belfast, 1845-1949: The History of a University (London: Faber, 1959), 1: 1-83.

21. Clifford Turney, Ursula By gott, and Peter Chippendale, Australia's First: A History of the University of Sydney, (Sydney: Hale and Iremonger, 1991), 1: 59.

22. Ibid., 59; Barry to Herschel, 27 Jan. 1854, Minutes of the Proceedings of the Council of the University of Melbourne, 10 Apr. 1854, UMA; Australian Dictionary of Biography $[A D B]$, 5: 134-36. 
preparation for industrial life, and might lead to a distaste for future occupations. Insistence on making them compulsory would diminish attendance at the university, impede the progress of other studies, and, in the end, depress the standard of classical leaming. Heam could not be accused of being prejudiced against Latin and Greek as, because of the early death of Henry Erskine Rowe, he was temporarily teaching them at the very time he was opposing their being made compulsory. Barry made no concessions and the classics remained compulsory for nearly a quarter of a century. The University of Melbourne was determined to compare well with the British universities, despite Hearn's anguished cry that colonial society was radically different from England and, using Sydney as an example, he insisted that 'the more closely...Colonial Universities resemble those of the Mother Country, the greater is the probability of their failure. ${ }^{23}$

Before the establishment of the university, the colony's schools had been strongly involved in teaching the modern subjects. After the promulgation of the matriculation regulations these subjects were forced to give pride of place to the classics. In defending the classics, in forcing this change, Barry had no doubt that he knew better than the schools what was good for them. He could hardly have made his position clearer. When attacking the views of those who thought the building of the university premature and who argued that it would have been 'more prudent had the series ascended through Grammar Schools and Colleges, to an University, rather than have begun with the highest in order,' Barry insisted that history showed that universities had preceded colleges and grammar schools, and that 'experience shows, also, that Colleges legitimately follow, spring from the exigencies of, and form a supplement to, Universities. ${ }^{24}$ Schools, if we may translate Barry into a more modern idiom, exist to meet the needs of universities. It is a tradition to which the University of Melboume has remained loyal through the nearly one hundred and fifty years of its existence.

Loyalty to that tradition reflects the determination of the university's administrators to control the education of those who rule Victorian society. For though the university was to be open to all, its founders were perfectly clear about what its products were to be: 'accomplished scholars, honorable practitioners in the different learned professions, respected magistrates, able leaders in the Senate, enlightened legislators, and trustworthy guides in the councils of the country,' Barry said. As its first building was going up the university's founders would sometimes drive out to the site on Sundays, bringing their wives with them, to watch the progress and to muse on the future. ${ }^{25}$ The university was a powerful

23. Musgrave, From Humanity to Utility, 20-22; $A D B$, 4: 370-72 and 5: 419-20; W.E. Hearn and W.P. Wilson, On the Proposed Course for the Degree of Bachelor of Arts in the University of Melbourne (Melbourne: Argus of fice, 1855), esp. 2 and 7.

24. Proceedings on the Occasion of the Inauguration of the University of Melbourne, 9, 11.

25. Ibid., 22; Emily Childers diary, 14 May 1855. 
symbol of the plans of those who ruled the colony and of their desire to prepare their successors.

At the same the idea of this university was rent with apparent contradiction and ambiguity. It was radical through its secularity (more marked, at that time, than any other university in Britain or its colonies), its rejection of the collegiate system, its state funding, its proclamation that its doors were open to all men irrespective of religion or class, its urban location. Yet when it came to teaching it clung to a conservative curriculum, privileging the classics over the utilitarian subjects. The contradictions dissolve when it is realized that the University of Melbourne had set itself the same task as had Oxford, Cambridge, or Trinity College, Dublin, the education of the society's leaders, but it had devised a different educational regimen which took into account the different social, political, and economic structure of Victoria.

As Martin Sullivan has shown, Victorian society, even before the discovery of gold, had already witnessed the production of classes, at least in the sense of employers of labour (pastoralists, squatters, merchants, businessmen, bankers) and wage labourers (shepherds, clerks, road navvies, tailors, domestic servants). There were Masters and Servants Acts to construct and reinforce these differences, and clear consciousness of the class divisions. Redmond Barry shared this consciousness, and when speaking on the immigration issue, announced that it would not be prudent 'to introduce many more of a class, (in General requiring better food and accommodation than laborers).' As early as 1842 the banker and squatter, Thomas Wills, was acutely aware of his class interest, though he came to a different conclusion from Barry. He insisted that without a continued supply of labourers, 'wages will again rise to such a rate as to render it impossible to carry on our pursuits without positive loss to all employers of laborers, and certain ruin to many.' The rulers of Victorian society crowd into the pages of the diary of Hugh Childers's wife, Emily, as they visit her home to work or socialize, to talk about the great dinner that Barry had given for the members of the university, to observe George William Rusden and his host play chess or, 'greatly to the discomposure of his H's dignity,' to watch Barry chase his horse around the garden. During the gold rushes Hugh Childers complained to his sister in England that there would soon be no clerks left in Melbourne while 'We, the unfortunate gentle people, are reduced to a most subservient state.' To his wife it was simply a case of 'the lower classes [being] rampant.' The unfortunate gentle people, their lives and society, have been the subject of two detailed studies by Paul de Serville. 'A view as it were from the club window,' he has described his work,

and a rough parallel of the grander, but still limited section of life observed from the bow window of White's and other clubs, where the 
dandies lolled, quizzing glasses erect, remarking upon the world which passed beneath their gaze in St James's Street. ${ }^{26}$

The twenty members of the first Council, nearly all of whose names crop up in Emily Childers's diary, reinforce this picture of a dominant class and gender structure. The twenty were men, it is worth saying again. Twelve of them had been to university, eleven were parliamentarians at one time or another, and twelve had strong pastoral or business interests. There were five clergymen (including two bishops), five lawyers, five medical practitioners (including two surgeons), and five civil servants. There were eleven Anglicans, two Catholics, two Presbyterians, a Quaker, a Congregationalist, and three whose religion I have been unable to determine, though probably they were all Anglican. Of the twenty, thirteen, perhaps fourteen, were at some time in their lives members of the Melbourne Club. And so were two of the university's first three professors, if one excludes Rowe whose colonial life of one month gave him little time to join. The clubbable first Council of the University of Melboume, whose names are engraved on that lost foundation stone, provides a vignette of the ruling classes of Victorian society. Having rejected so many of the traditions of Oxford and Cambridge, they did not reduce the importance of the classics, for they considered that the first task of the University of Melbourne was not so much to support an Establishment, but to establish one.

Newman (after whom a college in the university was later named) may be allowed the last word, for The Idea of a University, though about as old as the University of Melbourne, still catches the modern reader's mind with its originality and with the sometimes frightening clarity with which it exposes the choices that universities have made. "Quarry the granite rock with razors," he wrote,

or moor the vessel with a thread of silk; then may you hope with such keen and delicate instruments as human knowledge and human reason to contend against those giants, the passion and the pride of man.

Barry and his colleagues, heirs to the Enlightenment as they were, were seeking what Newman thought impossible — an educational promised land where students were made good people through the exercise of human reason, through knowledge, through the lectures of professors rather than through the formative influence of the intellectual and social life of a college. This promised land is

26. Martin Sullivan, Men and Women of Port Phillip (Sydney: Hale and Iremonger, 1985), 162-63; Emily Childers diary, 21 July 1853 and 22 Aug. 1852; Paul de Serville, Port Phillip Gentlemen (Melbourne: Oxford University Press, 1980), and Pounds and Pedigrees: The Upper Class in Victoria 1850-80 (Melbourne: Oxford University Press, 1991), ix. 
still all inside people's heads and has never been found. It never once beckoned to Newman. But, though the gap between them was large, Barry and Newman had some things in common. Universities for them were exclusive institutionsfor both of them they were preserves of the high culture, training grounds for the men, and the men only, who would control their differing societies. In his passionate defence of liberal education, of the humane studies against those which were merely useful, Newman delineated another area in which he and Barry could have found common ground: 'You see, then,' he said, 'here are two methods of Education; the end of one is to be philosophical, of the other to be mechanical.' As Jaroslav Pelikan has noted, Newman might as well have said 'here are two classes'- the one taught to think, the other to work, one to whom the university opens, the other to whom it is closed. Pelikan also points out that the classical civilization, which Barry so defended at the new University of Melbourne, was based on an assumption that services which a civilized man considered unworthy would be performed by an inferior section of the population. ${ }^{27}$

On that July day in 1854, when the new Council gathered around Governor Hotham in the mud to lay the foundation stone of the University of Melbourne, there were no slaves present, but both the classes Newman identified were there. While the ordinary colonists watched from a distance, some people, of whom Barry was one, had come in carriages and were inside the fence.

27. John Henry Newman, The Idea of a University, ed. Martin J. Svaglic (Notre Dame: University of Notre Dame Press, 1986), 85; Jaroslav Pelikan, The Idea of a University: A Reexamination (New Haven: Yale University Press, 1992), 42. 